\title{
Determinants of Nile tilapia's (Oreochromis niloticus) growth in aquaculture pond in Batu, Indonesia
}

\author{
EVELLIN DEWI LUSIANA ${ }^{1,2, \boldsymbol{v}}$, MUHAMMAD MUSA ${ }^{1,2}$, SYAHRIL RAMADHAN $^{1}$ \\ ${ }^{1}$ Department of Aquatic Resource Management, Faculty of Fisheries and Marine Science, University of Brawijaya. Jl. Veteran, Malang 65145, East Java, \\ Indonesia. Tel./fax.: +62-341-553512, `email: evellinlusiana @ub.ac.id \\ ${ }^{2}$ AquaRES Research Group, Faculty of Fisheries and Marine Science, University of Brawijaya. Jl. Veteran, Malang 65145, East Java, Indonesia
}

Manuscript received: 29 November 2020. Revision accepted: 25 January 2021.

\begin{abstract}
Lusiana ED, Musa M, Ramadhan S. 2021. Determinants of Nile tilapia's (Oreochromis niloticus) growth in aquaculture pond in Batu, Indonesia. Biodiversitas 22: 999-1005. Nile tilapia (Oreochromis niloticus) has been commonly cultured all over the world, especially in Indonesia, due to high market demand. The success of Nile tilapia culture production depends on the fish growth during cultivation as well as pond environment. Many studies have revealed that quality of water strongly affects fish growth in an aquaculture pond. This study aims to investigate the relationship among water quality like Physico-chemical (temperature, transparency, $\mathrm{pH}$, dissolved oxygen, carbon dioxide, nitrate, and phosphate) and biological (phytoplankton abundance) factors and the specific growth rate of Nile tilapia in a freshwater cultivation pond in Batu City, Indonesia. The data was analyzed using the path model. Results indicated that the most significant factor for fish growth was the phytoplankton abundance. However, since nitrate and phosphate also played roles as determinants of phytoplankton abundance, they can be considered indirect water quality factors of Nile tilapia growth.
\end{abstract}

Keywords: Nitrate, path model, phosphate, phytoplankton abundance, specific growth rate

\section{INTRODUCTION}

Nile tilapia (Oreochromis niloticus) has been widely cultured all over the world in response to high market demand; it is easy to breed, has the ability to receive additional feed well, and possesses a high survival rate and economic value (KKP 2010). However, most of the farmers involved in tilapia production, especially those from developing countries, still lack critical information about the cultural process. This in turn limits their ability to optimize production levels (El-Sayed 2006). Such optimization requires an understanding of the various changes in environmental factors that can impact managerial practices important to maximizing fish yield (Bajaj 2017).

There are many variables that determine the quality of a water body, such as temperature, dissolved oxygen, turbidity, transparency, carbon dioxide, $\mathrm{pH}$, alkalinity, nitrate and phosphate levels, primary productivity, biological oxygen demand (BOD), and plankton population (Bhatnagar and Devi 2013; Makori et al. 2017). Generally, factors influencing the growth of fish in aquaculture ponds can be categorized into two groups: abiotic and biotic. While light, water temperature, and chemical constitution are considered to be the most important factors in the first group, the second group consists solely of the single factor of food availability for fish, which would appear to have the greatest significance (Wingfield 1940).

Phytoplankton is one of the food sources for fish in aquaculture ponds. Because, it has the ability to perform photosynthesis, and plays an important role as a natural feed or primary producer for other organisms in the aquatic ecosystems (Vrede et al. 2009). The abundance of phytoplankton is highly associated with fish production in aquaculture activities, and it is influenced by environmental factors, especially the existence of nutrients in the form of nitrate and phosphate in water (Donald et al. 2013; Lusiana et al. 2019).

One of the production centers of Nile tilapia in Indonesia is found in Freshwater Cultivation, located in Batu city. There, the aquaculture ponds are supplied with water from the Brantas river basin (Lusiana et al. 2018). However, the Brantas river has suffered from water pollution as the result of many human activities that exist along with the river flow (Suroso et al. 2007; Yetti 2011). Domestic and industrial activities have created wastes, and various substances have been discharged into the water, which in turn can affect water quality, both physicochemically and biologically (Syandri et al. 2016). Therefore, further investigation of the influence of water quality on fish growth in ponds is needed. The purpose of this study is to identify the main environmental factors that determine the growth of tilapia fish in the aquaculture ponds in Batu. Many studies stated that environmental factors have direct impact on fish growth (Bhatnagar and Devi 2013; Makori et al. 2017). Thus, the relationship can be simply analyzed using linear regression and correlation approaches (Dauda and Akinwole 2014; Aho et al. 2018). However, phytoplankton, as the biotic factor in the water environment, are also strongly affected by other abiotic factors. Hence, a simple model (regression and correlation) is not sufficient to determine the main water quality factor influencing fish growth. We thus consider a path model to accommodate the complexity of relationships between water quality factors and fish growth. Moreover, this analysis enables to 
choose the most contributing factor to the growth of fish. Such information is important for the fish farmer to decide prioritization in water quality management.

\section{MATERIALS AND METHODS}

\section{Study area}

The study was conducted from February to April 2018 in the freshwater cultivation area in UPBAT (Unit Pengelola Budidaya Air Tawar) Punten, Batu City, East Java Province, Indonesia (Figure 1). It is a freshwater cultivation management unit under marine and fisheries service of East Java Province. The cultivation area receives water supply from Brantas River.

\section{Collection and analysis of samples}

In this study, water quality factors that comprised both physicochemical (temperature, transparency, $\mathrm{pH}$, dissolved oxygen, carbon dioxide, nitrate, and phosphate) and biological (phytoplankton abundance) variables were considered. Fish growth was measured in weight (gm). Temperature was measured in-situ using thermometer, while transparency using secchi disk. Furthermore, $\mathrm{pH}$ paper was used in-situ to obtain the level of $\mathrm{pH}$ and $\mathrm{DO}$ meter Lutron DO-5510 for DO of the cultivated pond waters. The rest parameters were observed ex-situ at laboratory. Nitrate and phosphate were measured using spectrophotometer UV-Vis Spectroquant Pharo 300. The sampling procedure was conducted every two weeks with five replication during near midday (Morsy 2011) after the fish given feed. According to National Standardization Agency or BSN, the frequency of feeding was three times a day as much as $3 \%$ of body weight (Sari et al. 2017).

\section{Specific growth rate}

We randomly collected 15 fish at each sampling period by using scoope net (Riswandha et al. 2015). The specific growth rate of the fish can be calculated by applying the formula (Hopkins 1992)

$$
S G R=\frac{\ln W_{t}-\ln W_{0}}{t} .100 \%
$$

Where, $\mathrm{SGR}=$ specific growth rate; $\mathrm{W}_{\mathrm{t}}=$ final weight (gram); $\mathrm{W}_{0}=$ initial weight $($ gram $) ; \mathrm{t}=$ duration of the observation (day).

\section{Path analysis}

Path analysis is the extension of linear regression into a model comprising multiple relationships in order to form a simultaneous equation system (Sarwono 2011). The analysis can only be used for variables with a minimum interval scale and that fulfill normality and linearity assumptions. Before performing path analysis, a path diagram must be built that illustrates the overall relationship of the analyzed variables, based on theoretical justification (Hair et al. 2019). Moreover, the data should be standardized based on normal standardization method (Lusiana and Mahmudi 2020). The steps in path analysis are, (i) building a path diagram, (ii) performing a test of normality (Kolmogorov-Smirnov test) and linearity assumption, (iii) performing a test of significance, (iv) applying trimming theory, and (v) identifying the most influential predictors to the response (Kurniawan et al. 2016). The initial construction of the path diagram in this study is depicted in Figure 2.
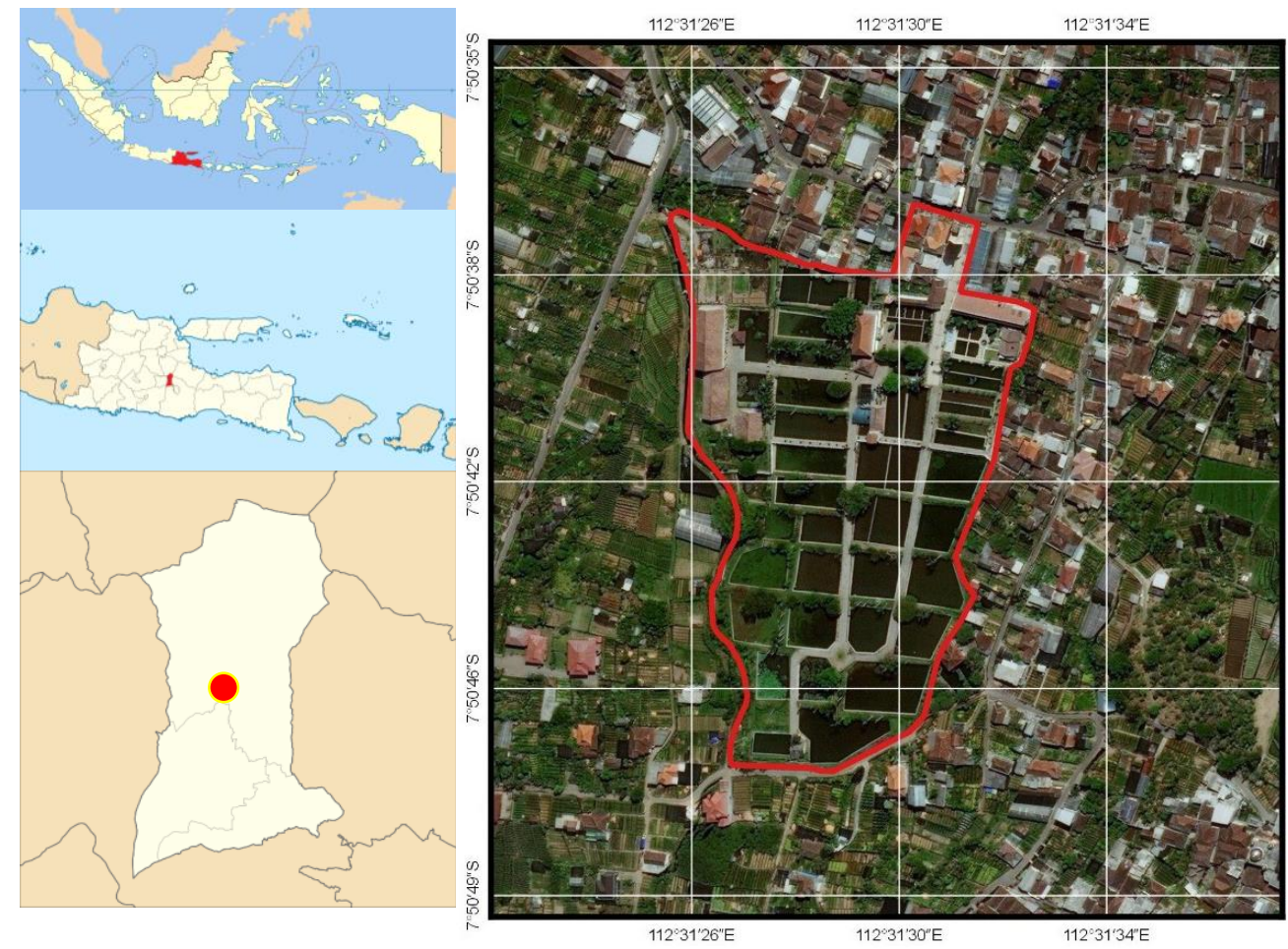

Figure 1. Study area location showing the aquaculture ponds in UPBAT Punten, Batu City, Indonesia (O) 


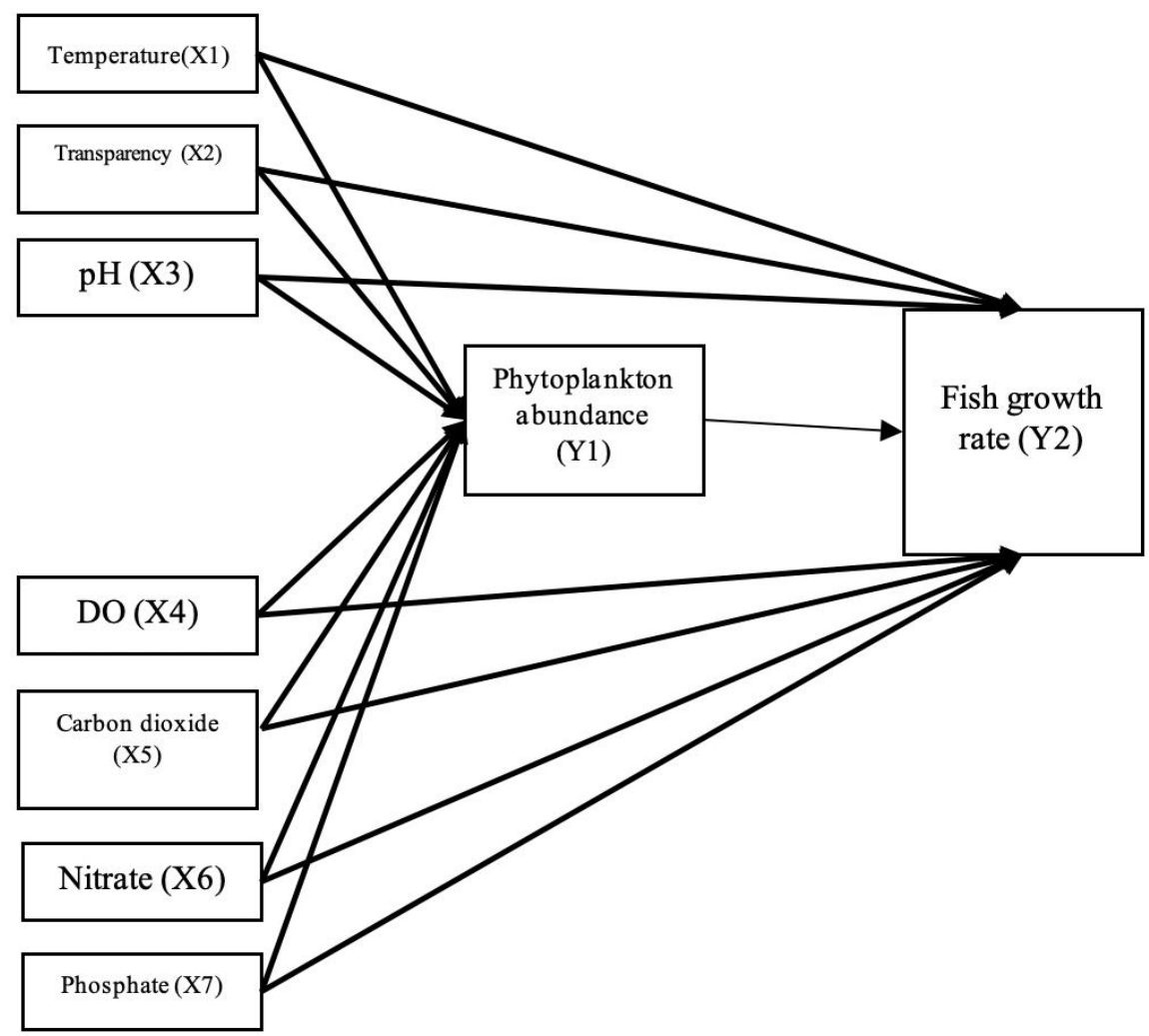

Figure 2. Complete path diagram for initial analysis for this study

\section{RESULTS AND DISCUSSION}

\section{Physico-chemical parameters of water}

Water temperature was recorded to be around 24 to $25^{\circ} \mathrm{C}$ during the study period (Table 1 ). This is classified as the optimum heat for tilapia culture, since the ideal range is 24-32 ${ }^{\circ} \mathrm{C}$ (El-Sayed and Kawanna 2008). Temperatures that extend over the boundaries of the range are most probably used to maintain internal physiology rather than growth. Transparency was observed to be between $26.3 \mathrm{~cm}$ and $34.3 \mathrm{~cm}$, which is desirable for aquaculture production (Bhatnagar and Devi 2013), and transparency of around 30$60 \mathrm{~cm}$ indicates optimum productivity of the pond (Singh and Ngachan 2007). Therefore, it can be said that the water clarity in the study site is optimum for tilapia growth. Notably, measuring transparency is an alternate step for roughly estimating the trophic state of a water body (Pavluk and bij de Vaate 2008). In addition, high content of fine sediment and organic particles will decrease the water transparency and affect the primary production of the ecosystem (Peck Yen and Rohasliney 2013)

As measured, $\mathrm{pH}$ was shown to be under 7; thus, the water was categorized as acidic. A suitable $\mathrm{pH}$ for fish culture is 6.7 and 9.5, and the ideal level for fish growth is 7.5 and 8.5 (Singh and Ngachan 2007). On the other hand, the concentration of DO in this study was observed to be around $6 \mathrm{mg} / \mathrm{L}$. As stated in a previous study, adequate DO for a fish pond is greater than $6 \mathrm{mg} / \mathrm{L}$ (Banerjea 1967); hence the pond in this study has a suitable DO rate for good fish growth.
Carbon dioxide $\left(\mathrm{CO}_{2}\right)$ concentration varied from 7.26 to $12.11 \mathrm{mg} / \mathrm{L}$, which is not favorable for fish growth, since the desirable limit for carbon dioxide in aquaculture is lower than $10 \mathrm{mg} / \mathrm{L}$ (Ekubo and Abowei 2011). The increase of $\mathrm{CO}_{2}$ in aquatic ecosystem did not affect the primary productivity, but it may shift the composition of phytoplankton to be dominated by harmful algae (Keys et al. 2018). The other important factor of water quality is the availability of nutrients, represented by nitrate and phosphate concentrations. Both the compounds in this study were favorable for fish culture with the good ranges of nitrate and phosphate from 0.1 to $4.0 \mathrm{mg} / \mathrm{L}$ and 0.05 to $0.07 \mathrm{mg} / \mathrm{L}$, respectively (Singh and Ngachan 2007; Bhatnagar and Devi 2013).

\section{Abundance and community structure of phytoplankton \\ Total phytoplankton abundance in the Nile tilapia pond} in Batu varied from around 8000 cells $/ \mathrm{mL}$ to more than 10000 cells/mL (Figure 3). The largest biomass was seen in the first and ninth weeks. Four divisions of phytoplankton within this abundance were identified: Chrysophyta, Chlorophyta, Cyanophyta, and Euglenophyta. Chlorophyta was the most dominant division, accounting for more than $40 \%$ of total algae, with a total of 12 genera (Cladophora, Chlorella, Scenedesmus, Spirogyra, Platymonas, Schroderia, Asterococcus, Chlorococcum, Pediastrum, and Straurastum). The abundance of Chrysophyta was ranging from 2678 to $3224 \mathrm{cell} / \mathrm{mL}$ and consisted of seven genera (Coscinodiscus, Cyclotella, Cymbella, Synedra, Gyrosigma, Nitzschia, and Navicula). Cyanophyta and Euglenophyta were the least 
abundant divisions, comprising five (Lyngbya, Choroccoccus, Oscillatoria, Phormidium, and Coelosphaerium) and two (Trachelomonas and Euglena) genera, respectively.

These results were inlined with the previous studies which suggested that Nile tilapia fish is effective in filtering Chlorophyta and Cyanophyta (cyanobacteria) from any water sources (Mohamed et al. 2019). It is also reported that the fish can feed on all types of Cyanophyta without any exception for toxic species (Xie et al. 2001). In addition, the long-term exposure of Nile tilapia to these species could accumulate the toxin in the fish tissue and potentially transfer it to upper trophic organisms (Mohamed et al. 2019). Therefore, the control of phytoplankton blooms especially Cyanophyta needs to be performed in the fish pond (Xie et al. 2001).

\section{Specific growth rate of Nile tilapia}

The specific growth rate (SGR) of Nile tilapia in the aquaculture pond displayed a fluctuation trend (Figure 4). The highest rate $(4.51 \%)$ appeared in the first week, followed by a constant decrease until reaching the bottom at the seventh week $(1.40 \%)$. After this, the SGR increased by $0.75 \%$. The dynamics in phytoplankton abundance over time as shown in Figure 3 have similar trend to SGR fluctuation in Figure 4. The maximum rate of SGR occurred along with the highest biomass of phytoplankton in the first week. Identically, the small number of phytoplankton in the seventh week seemed to be associated with the low SGR of tilapia. Hence, descriptively, those results depicted a tight relationship between phytoplankton abundance and growth rate.

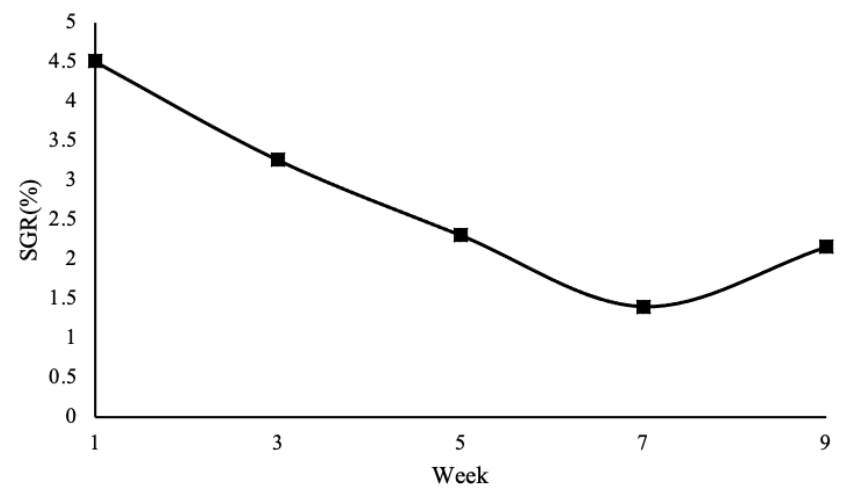

Figure 4. The SGR of Nile tilapia at aquaculture pond in Batu city, Indonesia

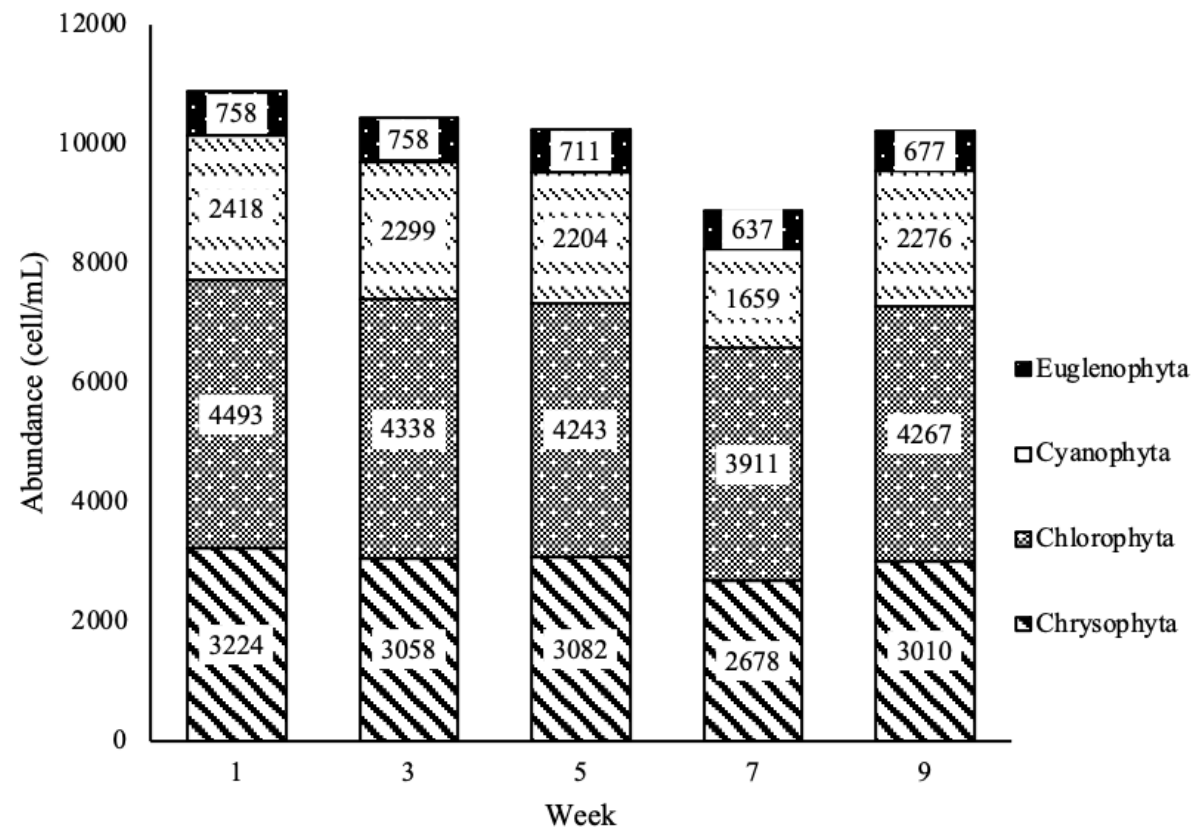

Figure 3. Phytoplankton abundance and composition during the research

Table 1. Physico-chemical parameters of water in Nile tilapia culture pond in Batu city, Indonesia

\begin{tabular}{|c|c|c|c|c|c|}
\hline \multirow[b]{2}{*}{ Variables } & \multicolumn{5}{|c|}{ Week } \\
\hline & 1 & 3 & 5 & 7 & 9 \\
\hline Temperature $\left({ }^{0} \mathrm{C}\right)$ & $23.8 \pm 0.764$ & $24.2 \pm 0.764$ & $23.7 \pm 0.577$ & $24 \pm 1.000$ & $24.5 \pm 0.5$ \\
\hline Transparency $(\mathrm{cm})$ & $29.2 \pm 1.607$ & $30.8 \pm 0.764$ & $32.2 \pm 2.466$ & $26.3 \pm 0.577$ & $34.3 \pm 3.512$ \\
\hline $\mathrm{pH}$ & $6.33 \pm 0.058$ & $6.63 \pm 0.115$ & $6.77 \pm 0.115$ & $6.5 \pm 0.000$ & $6.63 \pm 0.115$ \\
\hline $\mathrm{DO}(\mathrm{mg} / \mathrm{L})$ & $6.17 \pm 0.116$ & $6.56 \pm 0.307$ & $6.57 \pm 0.26$ & $5.98 \pm 0.502$ & $6.81 \pm 0.165$ \\
\hline $\mathrm{CO}_{2}(\mathrm{mg} / \mathrm{L})$ & $9.08 \pm 1.820$ & $9.69 \pm 2.102$ & $10.29 \pm 2.096$ & $7.26 \pm 1.815$ & $12.11 \pm 1.045$ \\
\hline Nitrate $(\mathrm{mg} / \mathrm{L})$ & $0.787 \pm 0.091$ & $0.853 \pm 0.05$ & $0.896 \pm 0.043$ & $0.478 \pm 0.014$ & $1.166 \pm 0.222$ \\
\hline Phosphate (mg/L) & $0.023 \pm 0.001$ & $0.024 \pm 0.001$ & $0.025 \pm 0.001$ & $0.013 \pm 0.001$ & $0.032 \pm 0.001$ \\
\hline
\end{tabular}




\section{Determinant of growth rate: path analysis results}

There are two assumptions underlying path analysis: normality and linearity. The normality assumption should be fulfilled by the response variables. This study engaged with two response variables: phytoplankton abundance (Y1) and fish growth (Y2). The Kolmogorov-Smirnov test showed that both the response variables were normally distributed $(p>0.05)$. Meanwhile, not all variable relationships in the path model have a linear association; only the relationship between transparency, nitrate, and phosphate to phytoplankton abundance, and phytoplankton abundance to fish growth complete the assumption. Consequently, those relationships that were not linear were deleted from the path diagram. Hence, a modified path diagram is shown in Figure 5A, along with the parameter estimation. As the effect of transparency is non-significant $(p<0.05)$, it was trimmed from the path model, thus creating the final path diagram in this study, as shown in Figure 5B.

The concentrations of nitrate and phosphate have a significant $(p<0.05)$ positive effect on phytoplankton abundance (Figures 5A and 5B). Generally, nutrient availability (nitrate and phosphate) is related to expanded biomass, and can prompt changes in the phytoplankton community. The abundance of phytoplankton frequently rises in number yet decreases in quality. Even when phytoplankton cells increase, remarkably, the quantity of species does not increase, which shows that there is a transcendence of specific species (Sidabutar et al. 2016; Wisha et al. 2018). On the other hand, Figure 5A showed that the influence of transparency on phytoplankton abundance was negative. The transparency of surface waters is often related to the amount of plant nutrients in the water. The greater the number of nutrients, the greater the number of phytoplankton, and, as a result, the less transparent water. In other words, as water transparency increases, algal abundance rapidly declines (Sterner 2009). However, unfortunately, it turned out that this relationship was insignificant $(p<0.05)$ in this study and was deleted from the final model. In addition, only phytoplankton abundance proved to have a direct significant effect on fish growth rate $(p<0.05)$.

In final path model, nitrate was the most dominant predictor of phytoplankton abundance in this study, since its total effect is greater than that of phosphate (Table 2). Meanwhile, the greatest determinant for fish growth is phytoplankton abundance. There are several reasons why phytoplankton is important for aquaculture. They are the foundational component of the natural web food and also used as a supplement for manufactured feed. This is especially significant for small, post-larval crustaceans and small fish soon after stocking; at noontime, these algae produce oxygen through photosynthesis at a faster rate than oxygen diffused from the atmosphere in the culture pond. Lastly, phytoplankton creates turbidity that restricts sunlight penetration to the bottom of the pond, and its bloom is a reliable monitor for aquatic macrophytes that grow under the water surface (Boyd 2016).

In conclusion, Nile tilapia's growth in an aquaculture pond is highly determined by environmental factors, both abiotic and biotic. This study showed that abiotic factors (nitrate and phosphate) have an indirect effect on the SGR of the fish, which was mediated by the biotic factor (phytoplankton abundance). This factor also became the greatest determinant of tilapia growth in the aquaculture pond in Batu. In addition, phytoplankton biomass itself was more strongly affected by nitrate concentration in the water body than by phosphate concentration.

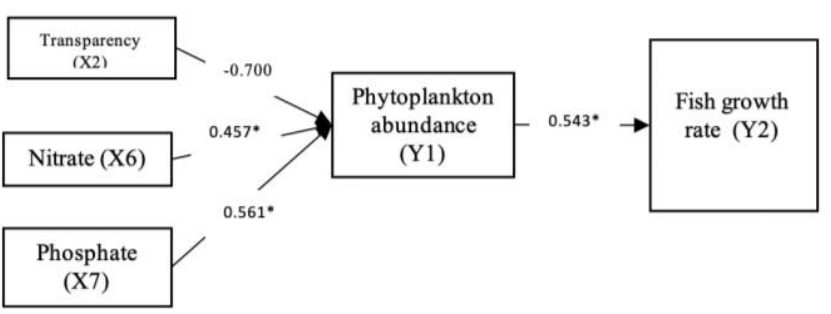

$\mathbf{A}$

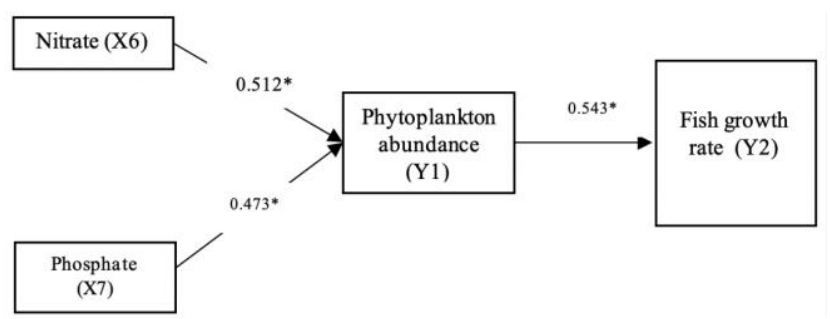

B

Figure 5. A. Modified path diagram after assumption test; B. final path diagram

Table 2. Direct, indirect effect, and total effect of final path model

\begin{tabular}{|c|c|c|c|c|c|c|}
\hline \multirow{3}{*}{ Predictor } & \multicolumn{6}{|c|}{ Response } \\
\hline & \multicolumn{3}{|c|}{ Phytoplankton abundance } & \multicolumn{3}{|c|}{ Fish growth rate } \\
\hline & Direct effect & Indirect effect & Total effect & Direct effect & Indirect effect & Total effect \\
\hline Nitrate & 0.512 & - & 0.512 & - & 0.278 & 0.278 \\
\hline Phosphate & 0.473 & - & 0.473 & - & 0.257 & 0.257 \\
\hline Phytoplankton abundance & - & - & - & 0.543 & - & 0.543 \\
\hline
\end{tabular}




\section{ACKNOWLEDGEMENTS}

This research was funded by a Penelitian Unggulan Grant from the Faculty of Fisheries and Marine Science, University of Brawijaya, in 2018. The authors thank everyone who helped to conduct this research.

\section{REFERENCES}

Aho MI, Akpen GD, Ekwule OR. 2018. Predictive regression models of water quality parameters for river Amba in Nasarawa State, Nigeria. Intl J Innov Eng Sci Res 2 (5): 24-33.

Bajaj S. 2017. Effect of environmental factors on fish growth. Indian J Sci Res 12: 87-91. DOI: 10.1002/047147844X.sw241

Banerjea SM. 1967. Water quality and soil condition of fish ponds in some states of India in relation to fish production. India J Fish 14 (12): $115-144$.

Bhatnagar A, Devi P. 2013. Water quality guidelines for the management of pond fish culture. Intl J Environ Sci 3 (6): 1980-2009. DOI: 10.6088/ijes.2013030600019

Boyd CE. 2016. Phytoplankton A Crucial Component of Aquaculture Pond Ecosystems. https://www.aquaculturealliance.org/advocate/ phytoplankton-a-crucial-component-of-aquaculture-pond-ecosystems/

Dauda AB, Akinwole AO. 2014. Interrelationships among water quality parameters in recirculating aquaculture system. Niger J Rural Ext Dev 8: $20-25$.

Donald DB, Bogard M, Finlay K, Bunting L, Leavitt P. 2013 Phytoplankton-specific response to enrichment of phosphorus-rich surface waters with ammonium, nitrate, and urea. PLoS One 8: e0053277. DOI: 10.1371/journal.pone.0053277

Ekubo AA, Abowei JFN. 2011. Review of some water quality management principles in culture fisheries. Res J Appl Sci Eng Technol 3 (12): 1342-1357.

El-Sayed A-FM. 2006. Tilapia Culture. CABI Publishing, Oxfordshire.

El-Sayed AFM, Kawanna M. 2008. Optimum water temperature boosts the growth performance of Nile tilapia (Oreochromis niloticus) fry reared in a recycling system. Aquac Res 39: 670-672. DOI 10.1111/j.1365-2109.2008.01915.x.

Hair JF, Risher JJ, Sarstedt M, Ringle CM. 2019. When to use and how to report the results of PLS-SEM. Eur Bus Rev 31 (1): 2-24. DOI: 10.1108/EBR-11-2018-0203.

Hopkins KD. 1992. Reporting fish growth: A review of the basics. J World Aquac Soc 23: 173-179. DOI: 10.1111/j.1749 7345.1992.tb00766.x.

Keys M, Tilstone G, Findlay HS, Widdicombe CE, Lawson T. 2018 Effects of elevated $\mathrm{CO}_{2}$ and temperature on phytoplankton community biomass, species composition and photosynthesis during an experimentally induced autumn bloom in the western English Channel. Biogeosci 15: 3203-3222. DOI: 10.5194/bg-15-3203-2018.

KKP. 2010. Informasi Kelautan dan Perikanan. Pusat Data, Statistik dan Informasi, Jakarta. [Indonesian]

Kurniawan A, Loekito L, Solimun S. 2016. Power of test path analysis and partial least square analysis. Cauchy 4 (3): 112-114. DOI: $10.18860 /$ ca.v4i3.3593

Lusiana ED, Arsad S, Kusriani, Buwono NR, Putri IR. 2019. Performance of Bayesian quantile regression and its application to eutrophication modelling in Sutami Reservoir, East Java, Indonesia. Ecol Quest 30 (2): 69-77. DOI: 10.12775/EQ.2019.010.

Lusiana ED, Mahmudi M. 2020. Teori dan Praktik Analisis Data Univariat dengan PAST. UB Press, Malang. [Indonesian]

Lusiana ED, Musa M, Ramadhan S. 2018. Penerapan model regresi kuantil untuk menganalisis hubungan panjang-berat ikan nil
(Oreochromis niloticus) di kolam ibat punten, Batu. J Fish Mar Sci 2: 166-172. DOI: 10.21776/ub.jfmr.2018.002.03.4. [Indonesian]

Makori AJ, Abuom PO, Kapiyo R, Anyona DN, Dida GO. 2017. Effects of water physicochemical parameters on tilapia (Oreochromis niloticus) growth in earthen ponds in Teso North Sub-County, Busia County. Fish Aquat Sci. 20: 30. DOI: 10.1186/s41240-017-0075-7.

Mohamed Z, Ahmed Z, Bakr A. 2019. Assessment of phytoplankton species in gut and feces of cultured tilapia fish in Egyptian fishponds: Implications for feeding and bloom control. Acta Limnol Bras 31: e27. DOI: $10.1590 / \mathrm{s} 2179-975 \times 8418$.

Morsy FM. 2011. A simple approach to water and plankton sampling for water microbiological and physicochemical characterizations at various depths in aquatic ecosystems. Ann Limnol 47 (1): 65-71. DOI: $10.1051 / \mathrm{limn} / 2010032$.

Pavluk T, bij de Vaate A. 2008. Encyclopedia of Ecology: Trophic Index and Efficiency. Academic Press, New York.

Peck YT, Rohasliney H. 2013. Status of water quality subject to sand mining in the Kelantan river, Kelantan. Trop Life Sci Res 24 (1): 1934.

Riswandha NS, Solichin A, Program NA, Manajemen S, Perairan S, Perikanan J, Perikanan F, Kelautan I, Diponegoro U, Soedarto J. 2015. Community structure of fish larvae in the mangrove ecosystem with different vegetation age in Timbulsloko Village, Demak. Diponegoro J Maquares 4 (4): 164-173.

Sari IP, Yulisman Y, Muslim M. 2017. Laju pertumbuhan dan efisiensi pakan ikan nila (Oreochromis niloticus) yang dipelihara dalam kolam terpal yang dipuasakan secara periodik. Jurnal Akuakultur Rawa Indonesia 5 (1): 45-55. DOI: 10.36706/jari.v5i1.5807.

Sarwono J. 2011. Mengenal path analysis: Sejarah, pengertian dan aplikasi. Jurnal Ilmiah Manajemen Bisnis 11 (2): 285-296.

Sidabutar T, Bengen DG, Wouthuyzen S, Partono T. 2016. The abundance of phytoplankton and its relationship to the N/P ratio in Jakarta Bay, Indonesia. Biodiversitas 17 (2): 673-678 DOI 10.13057/biodiv/d170241.

Singh NP, Ngachan SV. 2007. Guidelines for Water Quality Management for Fish Culture in Tripura. ICAR Res, Complex NEH Reg, Tripura Centre, Lembucherra

Sterner RW. 2009. Encyclopedia of Inland Waters: Role of Zooplankton in Aquatic Ecosystems. Academic Press, New York.

Suroso, Anwar MR, Rahmanto MC. 2007. Study of the Effect of Brantas River Sedimentation on the Capacity and Age of the Malang Sutami Reservoir Plan. Jurnal Rekayasa Sipil 1: 33-42.

Syandri H, Azrita, Niagara. 2016. Trophic status and load capacity of water pollution waste fish culture with floating net cages in Maninjau lake, Indonesia. Ecol Environ Conserv 22 (1): 455-462.

Vrede T, Ballantyne A, Mille-Lindblom C, Algesten G, Gudasz C, Lindahl S, Brunberg AK. 2009. Effects of N : P loading ratios on phytoplankton community composition, primary production and $\mathrm{N}$ fixation in a eutrophic lake. Freshw Biol 54: 331-344. DOI: 10.1111/j.1365-2427.2008.02118.x.

Wingfield BYCA. 1940. The effect of certain environmental factors on the growth of brown trout (Salmo trutta L.). J Exp Biol 17: 435-448.

Wisha UJ, Ondara K, Ilham. 2018. The influence of nutrient ( $\mathrm{N}$ and $\mathrm{P}$ ) enrichment and ratios on phytoplankton abundance in Keunekai Waters, Weh Island, Indonesia. Makara J Sci 22: 187-197. DOI: 10.7454/mss.v22i4.9786.

Xie S, Cui Y, Li Z. 2001. Dietary-morphological relationships of fishes in Liangzi Lake, China. J Fish Biol 58 (6): 1714-1729. DOI: 10.1111/j.1095-8649.2001.tb02325.x

Yetti E. 2011. 1 Jurnal Pengelolaan Sumberdaya Alam dan Lingkungan Evaluasi Kualitas Air Sungai-Sungai di Kawasan DAS Brantas Hulu Malang dalam Kaitannya dengan Tata Guna Lahan dan Aktivitas Masyarakat di Sekitarnya. Institut Pertanian Bogor, Bogor. [Indonesian] 